\title{
Possible consequences of the Employment Contracts Act for people with disabilities
}

\author{
Philippa Bascand* and Stephen Frawley ${ }^{\dagger}$
}

This paper briefly canvasses some issues that surround the employment of workers with disabilities in the new industrial environment under the Employment Contracts Act. The ability of employees with disabilities to negotiate contracts from a less than comparable position of strength is discussed. The underlying reasons for this imbalance in power is analyzed. The use of bargaining agents as provided for under the Act is discussed as one mechanism which may assist in addressing this imbalance in power.

\section{Introduction}

This paper considers some of the possible effects of the Employment Contracts Act 1991 for people with disabilities. It canvasses the significant issues regarding the ability of workers with disabilities to negotiate employment contracts from what is generally considered a less than comparable position of strength. It comments on the appropriateness of potential bargaining agents for this group of workers and on remuneration issues for new employees with disabilities who fall outside of a collective agreement. By way of introduction, it is necessary to first discuss the previous industrial framework of the Labour Relations Act 1987 and secondly, how the new environment under the Employment Contracts Act differs from this.

\section{The past framework}

The Labour Relations Act was established around the principle of collective negotiation between the appropriate trade union and representative employers' union. The Act, through a system of national awards and agreements, covered 6 out of every 10 employees in the New Zealand workforce. As a result of the "blanket coverage" clause of the Award, all employees, including employees with disabilities, whether union members or not, had collectively negotiated conditions of employment which were generally consistent within the workplace.

The Labour Relations Act also provided for Under-rate Workers' Permits to be negotiated into awards and agreements. These permits enabled the employee to receive remuneration below the award rate of pay. These employees were still covered by the award in respect of the other negotiated conditions due to the "blanket coverage" provision. Therefore, such matters as hours of work, penal and over-time rates, holidays, leave and training provisions which were negotiated into the award or agreement and were above the legal minimum requirements as laid down in the Holidays Act 1981 or Minimum Wages Act 1983, applied to all employees, irrespective of their rate of pay for the job. The Labour Relations Act also provided for personal grievance procedures to be 
available to only those employees who were members of a registered union and who were covered by the union rules. Employees who fell outside this framework were unable to access the personal grievance provisions of the Act. Furthermore, the personal grievance provisions failed to take into account the particular circumstances of people with disabilities; for example, employees with disabilities who had moved into the paid workforce from a non-unionized background, such as those moving out of sheltered workshops, but also ex-psychiatric patients who may have had intermittent periods of employment but not had the opportunity to establish sustained co-worker relationships or participate in work-related activities - such as union membership or union education forums. In these situations, people with disabilities were substantially disadvantaged by their own lack of awareness of union rights and services available from the union.

The exclusive rights of representation unions had over their members under the Labour Relations Act resulted in them being less inclined to actively recruit new members; especially workers who were in transitional employment states such as workers with disabilities moving from rehabilitative environments into work, or participating in the paid workforce on a less than full time basis. In addition, pressure on unions to police their own awards and to investigate personal grievances resulted in their limited resources being stretched still further, and meant they largely put their energies into their own members and, primarily, into able-bodied members. As one employer of a printing firm whose total staff is 4 workers with disabilities recently pointed out, "It was only when the Employment Contracts Act came into force that I even saw a representative from the union and then he came in with his papers all ready to sign up my staff". This example illustrates the indifferent performance some unions have given their disabled members.

For workers with disabilities - sometimes referred to as the "Invisible Minority", value for money questions need to be asked in respect of whether unions were giving the best possible service to employees with disabilities, given that employees with disabilities tend to be concentrated in industries with high rates of union penetration. A 1986 survey of Wellington private sector employers revealed people with disabilities were most likely to be employed in medium sized firms of between 101 and 499 personnel in the manufacturing, transport and service based industries (Bascand,1987). These industries, transport and communications, and manufacturing, as at the 1989-90 wage round, had union density rates of 75 percent and 65 percent respectively (Harbridge and McCaw, 1991). This is crucial in terms of the rights and opportunities available to bargaining agents (which includes unions) that intend representing employees with disabilities under the Employment Contracts Act.

\section{The new environment}

It is helpful now to review the 1991 Act and consider what impact the changes under it will mean for people with disabilities in the paid workforce. The Government's declared intention through the Employment Contracts Act was to promote efficiency in the labour market, foster enterprise through flexibility and allow employees the freedom to choose between individual or collective employment contracts. As the Minister of Labour stated, the Act:

gives employers and employees free choice as to their bargaining arrangements. Employees are able to choose whether they will negotiate 
directly with their employers, and which, if any, organisation or agent they wish to have represent them.1

The Employment Contracts Act was passed in a climate of high unemployment and low levels of business confidence. New Zealand's so called rigid labour market was cited as the major impediment to an export driven recovery. The Act was, thus, promoted by the Government as the panacea for many of New Zealand's economic ills.

The Employment Contracts Act is a radical departure from New Zealand's past industrial relations framework (Anderson, 1991). It provides for a far more permissive environment in which employees may "negotiate" - so called - either improved or reduced conditions of employment. The outcome of negotiations is more likely to be contingent on the bargaining framework and the state of profitability in a given industry. It is likely, under the Act, that a far greater disparity in conditions of employment will develop depending on the bargaining strength of the particular employees concerned. In short, there will be employees who will benefit from this new industrial environment and those who will not. It is vital that opportunities for people with disabilities to negotiate improved conditions are maximized and that any weaknesses in their bargaining power be minimized to the greatest extent possible in order to prevent their estimated unemployment rate of 40 percent rising still further.

There are 2 broad classes of employees affected by the new Act: those currently employed under an existing collective agreement; and potential employees. On expiry of a collective contract negotiated under the previous industrial framework, and until a new collective agreement or new individual contracts have been negotiated, all employees are deemed to have an individual contract of employment which has the same terms as the expired collective agreement. Recent moves by some employers to negotiate lesser terms have resulted in the Labour Court upholding the previous collective contract terms for existing employees. Therefore existing employees have the advantage that their conditions will be maintained indefinitely or until a new agreement is reached. This, of course, applies to currently employed disabled workers. New employees, however, depending on whether the collective contract has a clause covering their status, may be employed under conditions which fall below those of the old collective agreement. It is in this situation that potential employees with disabilities need accurate information, and access to advocates, to enable them to negotiate conditions which are at least equivalent to those that applied in the past.

The Employment Contracts Act also extends personal grievance procedures to cover all employees - not just unionized employees. Consequently, one of the few benefits to be seen for employees with disabilities under the new Act is that access to personal grievance procedures has been widened at an individual level, and that inexperience as a union member, or inadequate avenues of entry to the appropriate union, will no longer jeopardize that disabled employee's rights to take a personal grievance. In short, individual rights of access to the personal grievance provisions under the Employment Contracts Act have been strengthened at the expense of collective rights as contained in the Labour Relations Act. For employees with disabilities, the key issues then revolve around their ability to exercise their individual rights under the personal grievance procedures and the availability of appropriate advocates to assist in this process. It can be said these issues are pertinent to all employees, however, there are some distinct historical differences pertaining to disabled employees which means they are doubly disadvantaged. As noted earlier, irregular participation in union affairs - except in the public sector - has limited disabled employees' ability to fight for the maintenance of their employment conditions, and secondly; advocates for this group have tended to come

1 Opening address to Institute for the International Research Labour Relations Conference by Hon Bill Birch, Auckland, 1991. 
from within the social services sector rather than from an industrial background. Therefore the quality and or appropriateness of representation may be in doubt. We will elaborate on this point when we consider the choice of bargaining agents for new employees with disabilities.

Sheltered workshops and other voluntary welfare agencies have traditionally been large employers of people with disabilities. A 1989 survey by the Department of Social Welfare found over 8,000 people with disabilities to be participating in various forms of sheltered employment. Agency management, however, have tended to see the relationship within the organization not as one of employer and employee with its accompanying rights and obligations, but rather as a less structured familial and client relationship. As a result, an attitude of paternalism has been engendered on the employer's behalf, and no understanding has developed of the reasons for union representation on site, or the need for negotiated minimum conditions for staff. This role of the benevolent employer was reinforced by some charitable organizations receiving State protection from industrial agreements under the Disabled Persons Employment Promotion Act 1960 which effectively excluded union coverage and minimum industrial conditions for all employees on the workshop site.

Voluntary agency management have failed to see that benefits could be accrued by all parties through a better understanding of employment practices in addition to specific onthe-job skills training. General unease, lack of practical knowledge, and inexperience on the part of voluntary agencies in dealing with industrial issues such as sexual harassment or personal grievance claims, as well as concerns over the organizations' costs escalating upon entering the industrial arena, have combined to stifle debate and action in the area of minimum employment conditions. The effects of this lack of knowledge were largely mitigated under the Labour Relations Act by a comprehensive set of structures (i.e. national awards) setting out negotiated minimum pay and conditions. Under the Employment Contracts Act, knowledge of these human resource issues, and the wherewith-all to negotiate one's employment package, have become basic employment survival skills. More recently, the Community Services Union has provided an alternative for some employees with disabilities who work in the voluntary sector and for whom the option to join a stronger industry based union still remains out of reach.

Unlike other disadvantaged groups in the labour market covered by antidiscrimination legislation, people with disabilities are not included in the Employment Contracts Act as being able to take a personal grievance case on the grounds of discrimination due to disability, in the way that race or religion are covered. In the public sector, the majority of departments have made provision in their agreements for personal grievance on the grounds of disability, although no test cases have yet been taken. This is a positive example of how collective strength by a progressive union has assisted its disabled members, but it also highlights the way in which the new Act sets conditions at the lowest legal minima, and any conditions above that have to be negotiated into the collective agreement (Brosnan and Rea, 1991).

The Employment Contracts Act's main effect then, is to lower the floor of conditions for workers that previously existed under the awards and agreements structure. The minimum employment conditions are now to be found only in the Minimum Wages Act, the amended Holidays Act and the Parental Leave and Employment Protection Act 1987.

\section{The bargaining process}

The art of negotiation - of bargaining - of asking the right questions of what, why, how, and when, are crucial skills now expected of workers under the Employment Contracts Act. Workers who have limited work experience, and lack knowledge in respect of their own self worth in the market, will lack the ability to ask the right 
questions in order to negotiate the very important detail of the terms and conditions of their employment.

Negotiating successfully will require the following basic skills:

(1) a sound knowledge of specific job requirements and the ability to perform the specific job functions;

(2) the ability to actually get one's message across, i.e. the physical and intellectual skills that aid communication;

(3) an understanding of how workplaces operate, their structures, lines of authority, the significance they place on varying aspects of production;

(4) an ability to know your own worth and value to a given organization - knowledge usually gained through comparative experience in the work force or through gleaned information from colleagues in related professions.

Many employees, for various reasons, may not have had the chance to acquire these skills to any great degree; for example, new immigrant employees who are unfamiliar with our work practices and experience language and cultural barriers. In firms of fewer than 10 employees, which make up by far the majority of work places in New Zealand, employers' skills in the area of negotiation may be little better than those of their staff. In the past, employers of small workplaces have largely relied heavily upon the national awards and agreements framework for guidance in industrial relations issues, rather than having to develop expertise in such matters themselves. How then do these employers extend and develop their skills in this area, and build in sensitivity into the negotiating arena when encountering applicants or employees with disabilities? It is in such circumstances that the vulnerability of certain groups is exposed and the new Act fails to provide adequate safeguards.

People with disabilities may experience difficulties over and above those of ablebodied workers which can mar or interfere in the acquisition of basic employment skills, and therefore have a limiting effect on their chances of negotiating a fair and reasonable contract. These difficulties may include actual physical barriers to communication for the person directly involved in negotiation with the employer, through either sight or hearing impairments, intellectual dysfunction, or emotional instability; or the person may find themself at serious disadvantage due to structural barriers within the work environment such as discrimination, inaccessible communal facilities such as the "tea room", lack of peer or co-worker support, or incorrect information or assumptions noted about the person's disability on personnel documents. These latter factors, in particular, may prejudice preliminary discussions on the employee's contract prior to the person even setting a foot in the door.

\section{The use of bargaining agents}

How can this situation be helped? One way is through the use of bargaining agents who can provide additional support to the employee in putting their case to the employer (Walsh, 1991). Unions that have become sensitive to the needs of workers with disabilities, and have moved away from an ableist approach to one of inclusion, such as the Public Service Association, are able to assist in this process. A reliance by people with disabilities on an advocate or service agency to represent their interests in the negotiating process due to a physical communication barrier e.g. reliance on hearing interpreters, or because of intellectual limitations makes the picture more complex. A reliance on a third party may also arise because of a lack of experience and knowledge about real work situations due to having previously only been engaged in activities in a sheltered or voluntary work environment, or due to moving into the workforce at a relatively young age with few educational qualifications and therefore having a more limited value in the labour market and a reduced ability to negotiate reasonable pay and conditions. 
Whoever acts in the capacity of bargaining agent for the employee with a disability, a sound knowledge of the barriers experienced by that person on an individual level needs to be accompanied by a thorough knowledge of the work environment and present industrial framework. In this sense, social service agencies should be seen as an adjunct to the services offered by industrial relations specialists in the bargaining arena, and not as the primary advocates for people with disabilities seeking to establish a career path for themselves. In this way at least, bargaining agents can provide an important support to employees with disabilities, especially in the transition period from social support to paid work. On the negative side though, it must be noted that this reliance on third party intervention may, in fact, endorse the experience of many people with disabilities who are now moving out of institutions, and who are used to having decisions made for them by professionals on their behalf.

Bargaining agents should not, however, be seen as the only remedy for inequities in the negotiating process. There continues to be room for information on the benefits of equal employment opportunities programmes, and the management of diversity. Pressure on companies and public agencies to become more client responsive in the marketing and delivery of their services will complement initiatives in the area of EEO, and encourage employers to have recruitment practices which facilitate the entry of employees with disabilities.

\section{Impact for people with disabilities}

For potential employees with disabilities, as with other young people who are seeking to make the transition into the paid workforce from school, sheltered workshop or social security, the primary motivator is independence - the opportunity to become self-reliant, to earn an income and become self supporting and hence accepted into the adult community. There is some evidence that the Act is already having a depressing effect on wages and conditions of employment; for example, reduced penal and over-time rates in the recently settled agreements for the hotel industry and Wellington transport industry.

A position recently advertised with the New Zealand Employment Service for a "Person Friday" - a general do everything in the office type job - offered a salary of $\$ 13,000$. The Service was unable to fill the position at that salary level and passed it on to an organization involved solely in the placement of workers with disabilities. Does this infer that people with disabilities should accept those jobs at the bottom end of the spectrum? Or is there an underlying assumption that $\$ 13,000$ is an acceptable salary for a worker who otherwise may not even have a chance at a job?

Social Service agencies are caught in a double bind of having to meet the needs of the disabled individual and also of satisfying the employer and obtaining results - i.e. placing a person in a job in order to satisfy contractual obligations to government. The problem for the potential employee arises when multiple service agencies are involved in their placement into work, and each agency has a different perspective on that individual's output and standard of performance. For example, the Department of Social Welfare's perspective on the individual's ability to generate income is blinkered by their eagerness to have one less person on their books. On the other hand, a training provider or voluntary agency which has had a sustained relationship with the individual over many years may hold unrealistic expectations of that person's performance (either too low or too high) and be out of touch with the demands of the current labour force. There may also be a placement agency, such as the New Zealand Employment Service or Workbridge, involved directly in finding the person a job. None of these agencies can be seen to drive too hard a bargain with the employer in terms of wage levels in case they jeopardize their relationships with the employer and lose the placement, and potentially jeopardize their contractual relationships with government for funds. How then does the 
new employee who has little experience of the labour market, or of their value in the market, obtain comparative wage information, and gain the necessary confidence to argue for rates of pay at least equivalent to those already being offered in the industry to workers covered under the collective agreement?

\section{Conclusion}

It is still too early to assess the full effects of the Employment Contracts Act on the labour market generally, and specifically on employees with disabilities. The Act, in providing for direct negotiation between employers and employees, will make for winners and losers depending largely upon the bargaining strength of the parties involved. More questions than answers have been posed in this paper, but hopefully it will assist people to at least consider some of the issues. For employees with disabilities, a range of mechanisms is needed: at one level, a political response to the promotion of their employment rights, and yet in the immediate future, room obviously exists for bargaining agents to develop who have the appropriate skills to assist employees with disabilities to negotiate individual and collective contracts. Unions need to continue to develop inclusive policies and support their members with disabilities to fight for the maintenance of employment conditions in the first instance and secondly, enhance conditions for those same workers through the promotion of equal employment opportunity programmes.

\section{References}

Anderson, G. (1991) The Employment Contracts Act 1991: an employers' charter? New Zealand journal of industrial relations 16(2):127-142.

Bascand, P. (1987) Disabled people in employment: a survey of employers' attitudes. Wellington, Rehabilitation League NZ (Inc.).

Brosnan, P. and Rea, D. (1991) An adequate minimum code: a basis for freedom, justice and efficiency in the labour market. New Zealand journal of industrial relations 16(2): 143-158.

Harbridge, R. and McCaw, S. (1991) The Employment Contracts Act 1991: new bargaining arrangements in New Zealand. Asia Pacific HRM 29(4): (forthcoming).

State Services Commission (1990) The invisible minority. Wellington.

Walsh, P. (1991) Bargaining options under the Employment Contracts Act. New Zealand journal of industrial relations 16(2):167-174. 